$$
\text { ケニア・カンバにおけるキジーツ }
$$

—キロンゾのキジーツの事例研究——

$$
\text { 上田将* }
$$

$$
\begin{aligned}
& \text { はじめに } \\
& \text { I キジーツの形態と種類 } \\
& \text { II キジーッのカの隔䧺 } \\
& \text { III キジーツの所有者に及ぼすカ } \\
& \text { IV 真偽の判定のカとしてのキジーッ } \\
& \text { V ウオイとしてのキジーッ }
\end{aligned}
$$

\section{はじめに}

この小論はカンバ1)におけるキジーッ(kithitu, pl. ithitu) の力とその性質, およびその力の使用 に関する報告である.

キジーツの典型的な形態はカモシカ類などの動 物の角に呪薬 (muthea)を詰め込んで固めたもの である.これらの角などの容器は単なる呪薬の入 れ物ではなく，その中に詰められている呪薬と共 に一体となっており，この全体をさして人々はキ ジーツと呼んでいる.

キジーツは後述する如くその形態においてもそ の種類においても非常に多様である．ここではこ れらのキジーツ全般について述べることをしない で特定のキジーツについて述べたいと思う. カン バでは呪術的力の強力さの由にいつも人々の話題 にのぼるキジーツが存在している。キロンジ2)の キジーツもこら言った種類のキジーツである.キ ロンゾはすでに世を去り, 彼のキジーツは息子の

* 東京経済大学

1) カンバ (Kamba) はケニアに住むBantu 系の種 族で人口約 120 万人, 行政的には Machakos District と Kitui Districtに区分されている. 父系 出自で一夫多妻を原則とする社会である. 調查地 は Kitui Districtの最北端で灌木の生い茂る丵 林地帯である.この地域ではひえ, きび, 豆類を 栽培し, 牛, 山羊, 羊などの家畜を飼育する. 弓 矢を使用して狩椫も行なってきた。

2）氏名は全て仮名である.
ソゾカに受け継がれているが，現在でもキロンゾ のキジーツと呼ばれている。このキジーツはキロ ンゾが若い頃近隣の Mbeere ${ }^{3)}$ の呪医 (mundu mue) より購入したもので，人間の向ら脛の骨に 呪薬が詰められたものであると言われる.このキ ジーツはカンバの伝統的な裁判制度と密接な関連 をもっており，真偽を判定する力を所有してい る.このキジーツの前で虚偽の宣暂をした者に対 しては死をもたらすと信じられている．またこの キジーツは自分の競争相手や敵, 義務の不履行者 などに対して致命的な打撃を与えることができる と信じられている.

キジーツの強力さについての信仰とそれについ ての恐怖心は人々の心に深く根ざしているように 思える．伝統的な慣習に従らことを拒否する熱烈 なキリスト教信者も首長 (chief) や他のリーダー たちもキジーツに関しては例外ではない.

カンバのキジーツに関する従来の研究4) におい

3) Mbeere は Kamba, Kikuyu, Meru などと同様 に Bantu系の種族である。人口約 65,000 人 (1971 年), Embu District に居住する. 調査地 の北部 Kitui の西側に接しており，歴史的にも $\mathrm{Kamba}$ と関係が深い. Kamba の人々は Mbeere には強力な呪術的力を持っ呪医が多いと考えて いる。

4）従来のカンバの研究の主なものは, Hobley,C.W. 1967; Kimilu, D.N. 1962; Lindblom, G. 1920; Middleton, J. and Kershaw, G. 1965; Ndeti, K. 1971, 1972; Penwill, D. J. 1951; などであ る. 
ては, いずれの研究においても, 宣誓の儀礼とし てあるいは誓約の審判としてのキジーツの側面の みが取り扱われており，キジーツの持つもっと多 面的な性質についての吟味がなされていない。キ ジーツは一面ではまるで生き物のようで叢林 (kitheka) から家屋敷（musyi）までやって来た り，山羊の血が欲しいと言って泣いたりする。キ ジーツの所有者はキジーツにムワ (mwa) と呼び かけて親しい関係であることを表現する.キジー ツは所有者の言に従ってその力を発揮する．その 反面，キジーツは所有者自身にも何らかの破壊的 な力を及ぼす．所有者はキジーツの力のために男 の子供を持つことができないと言われる.

キジーツは前述した如く, 真偽を判定する力を 持つと同時に競争相手や敵を打倒するいわゆる “邪術”的な力をも所有している。ここではこう言 ったキジーツの力の多様性についてキロンゾのキ ジーッの事例でもって説明を試みたいと思う。

\section{I キジーツの形態と種類}

ここでは先ずキジーツの一般的な形態と種類に ついて概観しておきたい。

キジーツは動物の角, 人骨, 小型のひょらた ん，小さな布袋などに呪薬 (muthea) を詰めたも のである. 動物の角ではカモシカ類などの野生動 物の角や山羊などの家畜の角などが一般に使用さ れる. 強力な力をもつキジーツには通常は大カモ シカの角や人間の向う脛の骨などが使用されてい る. 人骨は最も強力なものだと言われる. また破 損した素焼きの监に呪薬を塗ったり，木切れに切 り傷を入れてそこに呪薬を擦り込んだものなども キジーツと呼ばれる. キジーツと称されるるのは この他にも様々な形態が存在している. キジーツ の種類も多様で, 例えば, 女性の不妊を治療する ためのキジーツ，牛泥棒や妖術者 (muoi wa mundu muka) を見張り，発見し，懲罰を与える キジーツ5)，踊りの競争に抢いて相手の集団の踊 りを靦乱し困乱に陥し入れるキジーツ (kithitu kya wathi), 牛の支払いに関するもめ事などで,

5) 上田 将 1975 (334 335 ページ) 参照.
ぞちらの主張が正しいかを判定するキジーツ (kithitu kya kuinga), 宿敵や競争相手を打倒す るためのウオイのキジーツ (kithitu kya. uoi) な どがある.これらのキジーツのうち，例えば，主 として病気治療や保護のために使用するキジーツ やあるいは盗難防止のためのみに使用されるキジ ーツがある. あるいはここで取り上げるキロンゾ のキジーツの如く同じキジーツが黒・白の判定の ために使用されると同時に宿敵や競争相手を打ら 倒す力を持っているキジーツも存在する. 力の強 さもキジーツによって様々なのである.

\section{II キジーツのカの隔離}

キロンゾのキジーッは他の強力なキジーツと同 様に家屋敷 (musyi) から遠く離れた叢林 (kitheka) の中に保管されている. 強力なキジーツの所 有者は自分の家屋敷の内部や近くにキジーツを置 くことは非常に危険であると考えられている. キ ジーツの持つ破壊的な力は所有者本人は勿論のこ と, その家族の者全体に影響し，次々に死者を生 じせしめると考えられているからである．刺の灌 木の小枝を積んで作った垣根で囲まれている家屋 敷の空間には, 盗難や妖術者を見張るためのむし ろその成員を保護する性質のキジーツやキインガ (kiinga) が置かれている. 家屋敷の内部は呪医 (mundu mue) に依頼して十分に保護してもらわ なくてはならない。これは家長の義務と責任であ る. 保護的なキジーツは家屋敷が見渡せる樹木の 上に置いたり吊したりされる。あるいは木に 7 つ)の切り傷を刻んで作ったキインガが家屋敷の 入口に立てられている. しかしキロンゾのキジー ツはこのような保護的な性質は持たず，むしろそ の破壊的な力の方が強調されるので人間の住む空 間である家屋敷には置くことはできないのであ る.キジーツが叢林の中に保管されれば, その力 は家屋敷の成員には影響を及ぼすことはない。こ のように叢林は家屋敷との対応?゙にいてキジー

6) 奇数は一般的には悪い数であると言われる。呪 術・宗教の領域では力強さの意味を持っ. 就中, 7 の数字は最も重要である。 
ツの力を隔離しておく場所であり安全な保管場所 である.

キジーツを隔離しておく場所は叢林の中であれ ばどこでも良いと言うわけではない，厳密に言え ばキジーツは叢林の中の岩山の裂け目の間に置か れなくてはならない。キジーツが地に直接触れて は大地を不毛なものにしてしまらからである.

このようにして保管されているキジーツに所有 者やキジーツを使用したい人々が近づく場合，あ るいはキジーツから離れる場合には一定の方法や 儀礼に従わなければならない。こうしないと身に 危険が及ぶのである。キジーツの前に出かけると きはまず山羊を 1 匹キジーツに供犠し，その血を 与えて慰無しなければならない。キジーッはア イム ${ }^{8)}$ (aimu, 死者の霊, 祖霊) と同様に山羊の 血が好物だと言われる. 血と共に肉も 7 切れ与え られる。

キジーツに与える山羊の血と肉を持ってキジー ツに接近するが，この場合その当事者は衣類を脱 いで素裸のままで接近しなければならない。人々 にその理由をたずねると，生まれたときの姿でな くてはならないと答える，あるいはまた衣類を着 けたままではキジーツの力が衣類の間に入って家 に危険を持ち帰ることになるからであると説明す る人もいる。このような説明の中ではキジーツは その力を辺り一帯に発散させているかの如くであ る。またキジーツによっては裸体のまま後向き に後ずさりするようにして接近しなければならな い. 前向きの通常歩くような近づき方では危険な のである.

キジーツから離れる場合はキジーツの力の一切 を除去してからその場を去らなくてはならない。 この力を身体から除去する方法は kamama p mukengesya と呼ばれる灌木の小枝を石で吒いて

7） musyi (家屋敷）と kitheka（丵林）は基本的な 分類の枠組みとなっている，例えげ霊的存在が aimu ma musyi (ムシのアイム) と aimu ma kitheka (叢林のアイム) に分類される.前者は所 属の明確な死者の霊や祖霊を意味し, 後者は所属 不明の彷徨している霊的存在を意味している.

8）上田 将 $1974 \mathrm{~b}$ 参照.
樹液をとり，これに白蟻の巣（土）を混ぜ合わせ たものでキジーツに触れた手のひら，キジーッの 置かれた地面を踏んだ足の裏（キジーツが使用れ る時は岩の裂け目より地面に移される)，キジー ツを見た目を拭きとるよらにして洗浄する。をた この他しばしば使用されるものは mwoyo ${ }^{9)}$ 之呼 ばれる胃の中の内容物である。これを上述の樹液 に混ぜてキジーツを置いた地面を清浄するのであ る.このようにして人々はキジーツの力が身体に 移らないように注意する．叢林の中でキジーッの 力を完全に取り去ってのち帰路につく，もしこの 除法方法をとらなければその力は本人のみならず 家族の者にも影響を与えると考えられている.

\section{III キジーツの所有者に及ぼすカ}

キジーツの所有者は呪医 (mundu mue) ${ }^{10)}$ であ る場合もあるしそうでない場合もある。キロンゾ はキジーツを購入してのち呪医だと見なされるよ らになった．彼の息子のンゾカ老人は若い頃から キジーツの父の手助けをしてきたが，ンゾカの場 合は呪医だとは見なされていない，強力なキジー ッの持ち主として恐れられてはいるが呪医とはは っきり区別されている.

キジーツの力とその性質に関連して興味深いこ とはキジーッとその所有者との関係である. ンゾ カ老人はキジーツを使用する際にキジーツに向っ て語りかけるが，その場合キジーッに対してムワ $(\mathrm{mwa})^{11)}$ と呼びかけたり，あるいは私の友よ (munyanyawa) と呼びかけたりする。これらはい ずれも親しい間柄での呼びかけの言葉である。ま

9) mwoyo は雨の精霊 Lala の教える病気治療にお いても使用される. mwoyo はカンバの宗教・儀 礼において重要なものである.

10） mundu mue は賢い人の意味である. mundu mue wa uoi (ウオイの呪医), mundu mue wa wathi (踊りの呪医), mundu mue wa kavyu (ナイフ の呪医)， mundu mue wa kuthuka（体内から悪 い物を取り出す呪医) などがいる，以上は男性の 呪医である.女性の呪医は mundu mue wa ngai （神の呪医）と mundu mue wa ngondu（薬の呪 医）などである.

11) 上田 将・上田冨士子 1975 参照. 
たこのような呼びかけの言葉ばかりでなく，キジ 一ツに話しかける言語表現そのものが親しい者に 物事を依頼したり懇願したりする形をとってい る. キジーツとその所有者は特別に契り合った関 係で，両者の間ではどんなことを言っても，ある いはどんなことを依頼しても少しも構わない関係 であり，秘密事を言い合っても外に漏れることの ない関係であることが強調される.

しかし他面キジーツの所有者はキジーツにはい つも気を配っていなくてはならない，山羊の血や 肉を与えることを䛱るとキジーツは叢林の中の岩 の割れ目から出てきて家屋敷までやってくる. 所 有者とその家族にとっては危険な状態になる，そ のような場合キジーツはまるで人間の泣き声のよ らな声を出して泣くのでキジーツが家屋敷の近く までやってきていることがわかる，泣き声を聞い た所有者はただちに叢林に出かけて裸になってキ ジーツに近づき山羊の血や肉を与えなければなら ない.このようにして十分に慰热しないとキジー ツは怒るのである.この点ではキジーツはアイム (aimu, 死者の霊, 祖霊) とよく似ている. アイ ムも人間の願いを聞いてくれる反面山羊や牛の血 や肉を与えて慰無しないと怒って恐ろしい存在に なるのである。

キロンゾのキジーッの現在の所有者であるンゾ カ老人の妻ムンベはキジーツの泣き声について次 の如く述べている。

「私が嫁に来たその夜，夫のンゾカはキジーツ の泣き声を聞いても決して人に言ってはいけない と言いました。 キジーツは夜拈そくやって来て泣 きます。それはまるで人の泣き声みたいです，私 は何度もその泣き声を聞きました。その都度夫は 山羊を殺しその血をこわれたひょらたんの器に入 れて持って行きました。こらしないと家の者はみ んな死んでしまらと言われます」

キジーツは一面においてはこのようにまるで生 き物のような性質を所有している.

キジーツの所有者は彼のキジーツを叢林に隔離 したり，山羊を供檥して慰無したり，その力を払 拭する儀礼を施行してその力の影響から逃れよう
とするけれども，度重なるキジーツの使用におい て何度もキジーツを握る (kukamata kithitu) た めにその影響から逃れることは困難だと言われ る. キジーツの力の影響はその所有者の男の子供 に現われ，そのために男の子供は一人も育たない のだと説明される．キジーツを握り続けているら ちにその力が所有者の血の中に入ってしまらから であると説明される. 所有者の女の子供には全く 影響しない。

また，キジーツの所有者に男の子供が育たない のはキジーツが主人 (所有者) に自分のみを可愛 がってもらいたいために, 他の男の子供がいるこ とを望まないのだとも言われる。キジーッはそれ 自体が極めて男性的な属性を備えている。 キロン ゾもンゾカも共に男の子供には恵まれずみな死亡 してしまったと伝えられている。キロンゾはキジ ーツを Mbeere の呪医 (mundu mue) から購入 した.このとき呪医はキロンゾに「もしこのキジ ーツを手に入れるならば良いことはないだろう。 男の子供は 1 人も育たなくなるがそれでもよい か」と念を押した，当時キロンゾは弓を射られて 死亡した兄弟の死の弁償 (maambo) を取り立て るのに非常に苦慮していた，相手がその殺人を認 めず死の弁償の支払いに応じようとしなかったか らである．遠くまで出かけて彼がキジーツを購入 したのはこの問題を解決するためであった． 彼は このキジーツの力によってその弁償を取り立てる ことに成功した。

キロンゾはキジーツを手に入れてのち人々から 呪医と呼ばれるようになり, 尊敬を受けると同時 に恐れられるようになった，そして次第に氏族 (mbai) $^{12)}$ のリーダー (muthiani) ${ }^{13)}$ としての地位

12） mbai (氏族会議) にはクラン (mbai) のレベルで 開かれるものとサブ・クラン (mbaa) のレベルで 開かれるものとがあるが, 通常の事件処理のほと んどはサブ・クランの段階でなされる.土地争 い, 家畜が畑を荒した事件，盜難事件，母親が息 子に呪いの言葉を吐いた事件，妖術事件，弓矢に よる殺傷事件，妻同士の争い，夫が妻を虐待した 事件，相続の争い，救済資金の募金など多くの問 題が解決される.

13) muthiani はかっての氏族のリーダーである．近 
を確立して行った．彼の名声は彼の所属する氏族 のみならず，遠方の Machakos 地方 ${ }^{14)}$ にまで及 んだと言われる．多くの人々がキジーツの力を求 めてやって来た．その度毎にキロンゾはキジーツ を握って彼等の要求に応じた。 キロンゾはいつも キジーツを取り扱っていたので男の子供に恵まれ なかった．キロンゾにはンゾカとワンブワの 2 人 の息子がおり現在でも健在である. しかしこの 2 人はキロンゾの本当の子供ではなくてキロンゾが 友人に頼んで生んでもらった子供であると人々は 説明する. 彼は年老いて動けなくなった時, 息子 のンゾカにもし男の子供が欲しいと思えばこのキ ジーツを握ることはしないよらにと忠告した. し かしンゾカは父の忠告にもかかわらず依頼者から 入る金の魅力に惹かれてついキジーツに手を出 し，その使用を中止することができなかった．彼 はキジーツを恐れながらも最近まで使用して来た のである. ンゾカの男の子供たちもキジーッのた めに死に絶えてしまったと言われる．ンゾカの主 妻 (kiveti kinene) のムンべの説明によると，彼 女は男子 5 人，女子 5 人を出産した。男の子供は 5 人とも幼児あるいは少年時に死亡し, 女の子供 は 1 人が死亡した，彼女によると男の子供の死の 原因は 1 人は妖術 (uoi wa mundu muka，女の ウオイ）のためであり，他の 4 人は家に伝わるキ ジーツのためであると言う.女の子供の死はキジ 一ツとも妖術とも関係がないと説明する. ンゾカ の第 2 番目の妻 (kiveti kya keli)には男の子が 1 人いたが，1971年私たちが滞在しているときに死 亡した. この少年の死についての村人の説明もこ のキジーツのためであった. 丁度この頃 Mombasa

隣種族との戦いにおいていっも先頭に立ち, 敵状 探知の才に長けていること, 雄弁家であること, 飢䭊において雨を降らせる力を持つこと, 狩橅の 際に象などの動物を立ち止まらせる力を持つこ と, 氏族の成員を統率する力を持つことなどが重 要な資質であった. muthiani は呪術的力を背景 に持っていた. 現在の氏族のリーダーは chairman と呼ばれ, muthiani とは全く異質なもので ある.

14）Kitui 地区と Machakos 地区の両地区の間には 言語的にも種々の慣習においても若干の差異が 存在している.
(ケニアの海岸都市)よりやって来た男の依頼によ りキジーツを使ったためであると言われている. こうしてンゾカは男の子供をみな失ってしまった のである. その後 1972 年同じく Mombasa から ある男がこのキジーツの噂を聞いて，それを使用 するためにやって来た. この時はンゾカ老人は地 域のサブ・チーフに相談して助言を得ている.こ れ以上キジーツを使用しては今度は妻や女の子供 にもその影響が及ぶかも知れないという危惧の念 からキジーツを使用することを断念した. この 時, キジーツの 1 回の使用のために相手が提示し た值段は 300 シリング (約 15,000 円) であった.

男の子供の死は呪術の領域と深くかかわり合っ ている.このようなキジーツの場合のみならず, 女のウオイ (uoi wa mundu muka, 妖術) や呪 いの言葉 (ndeto nthuku) とも密接に関連してい る.

女のムオイ (muoi wa mundu muka, 妖術者) から非常に強力な女のウオイを購入する場合, こ れは余程親しい関係でないと困難なことだと言わ れるが，女のムオイはその代価として購入者に牡 牛を 1 頭支払らように要求する. この時の牡牛と いうのは男の子供のことを意味しており, 購入者 が強力な呪術的力を手に入れて家に帰った直後自 分の男の子供が死亡する。ここでもキジーッと同 様に強力な呪術的力を得れば男の子供を犠牲にし なければならないのである．どちらか一方を選択 しなければならないのであって両方とも手に入れ ることは不可能なのである.

また息子に不当に取り扱われた年老いた母親は 呪いの言葉を吐くことができる，この言葉の決ま り文句は打前はよい目を見ないだろらとか，無意 味な人生を送るだろらといら表現である。これは 子供の死, 就中, 男の子供の死を意味している.

カンバの男性にとっては男の子供を持たないで 一生を終えることは，その人生そのものが全く無 意味 (mana) であったことを意味する. 男の子供 はサブ・クラン $(\mathrm{mbaa})^{15)}$ の出自を継承し, 家族

15) 同じ mbaa (サブ・クラン) の成員は相互の系譜 の認知が明確である. mbaa の始祖は 7〜8 世代 さかのぼる. mbaa は外婚の単位である. 
や父系出自集団 (musyi) ${ }^{16)}$ の勢力を拡大する要に なるものであることに違いないが，彼等にとって 本質的に重要なことは子供が自己の生の持続であ り生の再生そのものと不可分の関係にあるという ことである.

\section{IV 真偽の判定のカとしてのキジーツ}

キジーツは人々の主張が相異なる場合，そのど ららの主張が正しいかを判定する力を持つと信じ られている.この側面におけるキジーツの力は裁 判や事件処理と密接な関連をもつものである.

カソバでは紛争処理の会合 (ikoani) において 議論が激しくなると, 言い争っている両者は「そ れじゃ，キジーツに行こうじゃないか」(Tuthi kithituni.) とよく言う。これは自分の言っている ことが正しいことを主張する表現でもある。「キ ジーツに行こう」と掗いが言い張っても，すぐ にキジーツに出かけるわけではない。このような 場合, 会合に参加している古老たち (atumia) ${ }^{17)}$ 首長 (chief) ${ }^{18)}$ や副首長 (sub-chief) はキジーツ は非常に危険であるから思いとどまるように争い 合っている両者を説得するのが常である. しかし 両者があくまでもキジーツに行くことを主張する ならば，キジーツで決着をつけることになる，紛 争の当事者はキジーツの持ち主のところに送ら れ, 古老たち, 首長や副首長, その事件の関係者 たちの立合いの下にキジーツを前にして自分の主 張が正しいことを誓ら。この儀礼を導びく者はキ ジーツの所有者である.このようにしてキジーツ

16) mbaa（サブ・クラン）はその下部単立の musyi に分かれる. musyi は伝統的には居住を共にする $3 \sim 4$ 世代前の先祖（あるいは現存する人物）を 共通汇持つ父系出自集団である. musyi はまたそ の家屋敷をも意味する。

17) mutumia (pl. atumia，古老) は男性のみを言う. 氏族会議や地域の会合における決定はいっる複 数の古老住よってなされる. 宗教・儀礼の側面の みならず現在の地域の政治に拈いても行政官, 首 長(chief), 副首長 (sub-chief) との提携を保ちな がら重要な役割を果している.

18） chief (首長) はいわゅる伝統的な首長ではない。 白人の統治が始って導入された制度で 1 行政区 (division) に 1 人の首長がいる.
に誓うことを kuinga kithitu (キジーツに誓うこ と）とか kuya kithitu（キジーツを食べること） と言う。これは kusuna kavyu (熱したナイフを 甜めること）や kuya muma ${ }^{18)}$ (ムマを食べるこ と）と本質的には同じ儀礼である. しかしこれら の判定の仕方の中ではキジーツが最も効果的であ り，偽りの宣誓をした者には確実に死がやってく ると言われる．遠方から来た者でキロンゾのキジ ーツの恐ろしさについて十分に知らない者は半信 半偽でキジーツの前で宣誓して死亡したと伝えら れている.この力についてよく知っている者はキ ジーツの前に出ることを恐れるのである.

キジーツの前で䇾ら場合にはいきなりその前に 出ることをしないで，その前段階としてクスナ・ カビュ (kusuna kavyu)を行なう.キロンゾのキ ジーツはこの前段階の儀礼を伴っている. キジー ツの前でひとたび宣譬するならば, 前言を翻して その宣誓を取り消すことは不可能なことで，嘘を ついたら確実に死がやってくると考えられている からである. クスナ・カビュは直訳するとナイフ を舐めることの意味である，これはナイフの呪医 (mundu mue wa kavyu) あるいはナイフの老人 (mutumia wa kavyu) によって白色の呪薬 (iga) を塗られ，熱せられたナイフを言い争ら者が舌で 甜める儀礼である. その結果舌に火傷を負った者 が嘘偽の主張をしていたことになる．しかしクス ナ・カビュはしばしばその文字通りの意味ではな く，もっと広い意味に使用される. キロンゾのキ ジーツの前段階としてのクスナ・カビュも実際に 熱したナイフを舐めるわけではない。言い争ら両 者の手のひらや額に白色の呪薬 (iga) を塗ってそ の呪薬の色の変化を見る. その呪薬が変色した方 が噓偽の陳述をした方だと判定される．あるいは またこの呪薬を両者の舌に縦に線を引き，しば らくして唾を吐かせる. 彼等の表現によると血 (nthakame) を吐いた方が噓をついていることに なる. このような判定の仕方の場合もクスナ・カ ビュ（ナイフを甜めること）と呼ばれる，呪薬が 変色すること,つまり虚偽であると判定されるこ

19）上田 将 $1974 \mathrm{a}$ 参照. 
とを人々はあたかも火傷をしたかの如く，文字通 り「ナイフで焼かれる」(kuvya ni kavyu) と表 現する.

クスナ・カビュで「火傷をした人」つまり黒だ と判定された人はこの段階で自分の非を認め, あ るいはその判定を受け入れて争いに終止符を打つ ことが出来る.この儀礼に立ち合ら人やキジーッ の所有者は，この段階で終了するように勧告する のが常である．その場合キジーツが如何に危険な ものであるかその当事者たちに説明される，それ でも納得しないで自分の方が正しいことを主張し ようとすれば，キジーツまで行くことになるが， 実際にはこのクスナ・カビュの段階で解決する場 合が多いのである.

キジーツと結びつき易い紛争や事件はいずれも その真偽を知るのに困難な問題ばかりである. 牛 や山羊などの家畜の返済についてのもめごと，未 婚の妊娠の認知についてのもめごと，妖術 (uoi wa mundu muka) に関する事件などはその典型 である.

カンバに拈ける家畜の支払いは婚資 (ngasya， 通常は牛 12 13 頭, 山羊 30 50匹) をはじめ, 人を死亡させた時の牛の弁償 (maambo)，人を怪 我させた時に支払ら山羊，「血を返えす山羊」 (mbui ya kutungia nthakame) など多方面に及 んでいる.この種の支払いは古老たちの立ち会い の下で厳密になされるもので，カンバに执いては 非常に重要なことである. 彼等の家畜についての 関心は絶大なものである。これらの家畜の支払い のことでキジーツに発展する争いになるのは，例 えば，離婚に伴なら家畜の返済や人に預けていた 場合の家畜の返還についてである．カンバの慣習 によると, 返済を要求されている牛が先方で子供 を生んだ場合には，その子牛も親牛と一緒に返え されなければならない。この問題は非常に解決が 困難である. 一方は子供が生まれたことを主張 し，もら一方は生まれていないと主張するからで ある.この種の家畜に関するもめごとは深刻な争 いに発展するのが一般である. キジーツの前で誓 らことが決定して，いよいよその当日になってそ
の宣誓を拒否した者は自分の非を認めたとされ， 支払いに応じなければならない。

未婚の娘が妊娠した場合にはその相手の男が誰 であるかを確認しなければならない，その男は娘 の父親に山羊を一匹与える義務がある. また出産 の際にもし娘が難産の場合には娘の家に行って酒 を地に注いで，子供が無事出産するようにアイム (aimu, 死者の霊, 祖霊) に祈願しなければなら ないのである．娘の妊娠の認知をめぐって娘の名 指した男が妊娠の責任は自分にはないことを否定 することによって争いに発展するのである. カン バではこのよらな場合子供を認知してもその父親 であることを主張することはできない.山羊の支 払いと前述の安産のための儀礼の終了でその娘と も子供とも一切関係はなくなるのである.

妖術 (uoi wa mundu muka) に関する紛争も キジーツと結びつき易い.キロンゾのキジーツの よらな強力なキジーツと関係をもつのは男性であ る. その所有者もその場に立ち合ら者もまた争い を起こしてキジーツにやって来る者も男性であ る. しかし女性が全くないわけではない.女性が キジーツにやって来るのは妖術事件の場合がほと んどである、つまり妖術者 ${ }^{20)}$ (muoi wa mundu muka）であるといら風評を立てられた女性がそ のことを否定するためにやって来るのである. 彼 女たちはキジーツの前で次の如く誓らのが一般で ある.「もし私が妖術者であるならば, このキジー ツによって私に死を」あるいは「私が妖術者であ るなどとありもしないことを言いふらしている嘘 つきはこのキジーツで死ぬよらに」などである.

妖術者であると言う風評が次第に定着してゆく 過程は単純なものではなく種々の要因が複雑に絡 まり合っていると考学られる ${ }^{21)}$. その過程を辿っ て妖術者と呼ばれることの不当さを証明しようと しても，それはほとんど不可能なことであるに違 いない、病気や死などの厄災の原因はしばしば妖 術者のせいに帰せられ，その女性が誰であるかの 判定は呪医, 就中, 診断の呪医 (mundu mue wa

20）カンバにおける妖術者は例外なく女性である。

21）上田 将 $1974 \mathrm{a}$ 参照. 
kugausya)によってなされる.その確認のために は数人の呪医の診断が一致する必要があると言わ れる. かつては妖術者は kingole と呼ばれる石打 ちの刑で処刑されたがこの場合には少なくとも 4 名の呪医の判定が一致することを必要としたと 言われる. しかしこのような診断の過程は患者の 側の過程であって妖術者には通常においては知る 方法はないのである．妖術者には誰もこのような ことについて話そうとはしないからである。しか しこれは滅多にないことではあるが，直接面と向 って妖術者であると名指して問題になることがあ る.このような場合には妖術者だと言われた女性 は名誉を傷つけられたとして氏族会議や紛争処理 の会合に提訴する，現在では妖術者だと名指した ことが明らかになれば，その名指した者は相手に 罰金を支払わなければならない，妖術事件の場合 は山羊 7 匹が支払われる。しかしこれで妖術事件 が全て解決したわけではない。このような事件は 妖術者としてのイメージをむしろ強める結果にな り，妖術者としての世評を固定化してしまう。

ンゾカ老人によると多くの妖術者がキロンゾの キジーッにやってきて死亡したと言う．彼が記憶 している限り 26 名の妖術者が宣誓後死亡したと 説明している.

\section{V ウオイとしてのキジーツ}

キロンゾのキジーツはしばしばウオイ（uoi）と 同義語に使用されたり，あるいはウオイのキジー ッ (kithitu kya uoi) と呼ばれたりする.これは キジーツが前述した黒白の判定とは異なったもら 一つの側面において力を発揮することを示してい る. 従来のカンバのキジーツに関する研究におい てはこの側面についての分析が久落していること は前に指摘した通りである．私はキジーツをウオ イのシステムの中で捉えてみる視角が必要だと思 う. 前述した真偽の判定のためのキジーツが裁判 や氏族会議との密接な関連で公の形でなされると すれば，ウオイのキジーツはむしろどちらかと言 えば個人的な使用が特徵であり，乙か子秘密のう ちになされるのが原則である. 前者が正義や真実
の主張の最終的な判定方法だとすれば，後者は敵 や競争相手から絶えず悩まされ続けている問題を 解決する最終的な方法だと言えよう。

ここでウオイについて簡単に触れておきたい。 ウオイ (uoi) は一般的には人生の危機と密接に関 連しており，様々な厄災・不幸事・不運・難橴な どを炭き起こす呪術的力である. もっと具体的に は人間や家畜の病気・怪我・死・不妊, 農作物の 不作・枯渴, 更に人間の不成功, 飲酒への耽溺な どをもたらす呪術的力である，そしてウオイの力 は創造主 (mulungu) や神 (ngai) や死者の霊・祖 霊 (aimu) などの怒りや懲罰とは直接関係はな く，ウオイの力を発揮したり，行使したりするの はあくまでも人間である.ここにウオイの特徵が ある. カンバの人々はウオイの力を大きく 2 つの カテゴリーに分類している．即ち男のウオイ (uoi wa mundu ume) と女のウオイ (uoi wa mundu muka）である.このように呪術的力が男性，女性 といら性的原理で分類され把握されているところ にカンバのウオイの特徴がある.

ウオイのキジーツは男のウオイの領域に属して おり, 男性 (mundu ume) のイメージと深く結びつ いている。 カンバに打ける男らしさの観念と不可 分の関係にある. そして男のウオイの特徵が述べ られる場合はいつも女のウオイがその根底に横た わっている.この両者の相違についてカンバの人 々にたずねると，男のウオイは呪薬 (muthea) を 使用するが，女のウオイは身振り・仕草 (shama, sing. kyama) だけであるといら返事が返ってく る.この説明は両者の特徵を大変簡潔に示してい る.

女のウオイを所有すると信じられている女性 (呪医ではない) を人々は妖術者 (muoi，あるいは muoi wa mundu muka) と呼んでいる. 彼女は 人にわからないような身振りや仕草でもって女の ウオイを発揮させているのだと説明される，妖術 者の場合は彼女の身体自体がその力の源泉であっ て，呪薬 (muthea) などには依拠しない，身体内 に所有され，母から娘へと女系を経て伝えられた 女のウオイの力は目くばせ, 顔の表情, 言葉, 手 
の動き，身体全体の動きなどによって発散され $3^{22)}$.女のウオイは一種のボディ・シンボリズム である.

これに対して男のウオイは呪薬の使用を必須な ものとしている，呪薬は呪医によって作られる。 キジーツなどのウオイの呪薬はウオイの呪医 (mundu mue wa uoi) によって作られる. 呪薬 を作る過程は，一面では技術的である．例えば叢 林の中の樹木の選び方，イガ (iga) と呼ばれる呪 薬を木の根元につけて呪薬のために最適な真直な 根を堀る堀り方, 数種の木の根をこわれた素焼き の壹 (mbisu) に入れて火にかけ，黒焦げにして 粉末にする仕方，このようにして出来た黒色の呪 薬 ${ }^{23)}$ を動物の角に詰めて白色の呪薬 (iga) と赤色 の土 (mbuu) で線を描いて密封する仕方などであ る. 呪薬は叢林 (kitheka) の樹木に関する広い知 識を背景として作られ，一般には植物性のものが その基調になっている，呪医や古老に呪薬やキジ 一ツの作り方を教えてくれるよらに依頼すれば, その製作過程を具体的に示してくれる. しかし， 呪薬の内容を知ることは不可能に近いことであ る，呪薬はそれを作る呪医に特有なもので，強力 な呪薬ほど秘密にされるからである．また保護呪 術の方が優っていればウオイを使用した呪医はそ の対抗する力のために死亡すると言われている.

呪医と呪薬の関係は死者の霊 $(\mathrm{aimu})$ と深く結 び着いている．真の呪医は自分が「2 本の呪薬の 小枝 (miti)」を手のひらに握って出生したことを 睡眠中 (夢ではないと彼らははっきり言ら)に死者

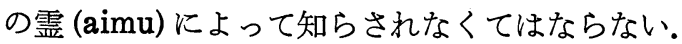
睡眠中に訪問する死者の霊は先輩の呪医の霊であ ると言われる。このような死者の訪問により自分 が呪医として生まれてきたことをはじめて知り， その後, 呪医としての訓練を開始するのである ${ }^{24)}$.

また，呪薬の持つ力はそれを製作する呪医の力

22) 上田 将 1975 (327 328 ページ) 参照

23) 黒色の呪薬 (muthea) は強力な力を持っと見なさ れウオイのために使用される. 白色の呪薬 (iga) には破壊的な力はなく，ある結果を効果的に導き 出したりする場によく使用される.
と密接に関連していて，呪医の社会的評価と不可 分の関係にある. カンバの人々はより強力な呪医 を求めて遠方まで旅をするのである.

ウオイのキジーツに関与することが出来るのは 男性である。この種のキジーツを使用する者は男 性でなくてはならず，またこの力が向けられる相 手も成人した男性でなくてはならない，女性や子 供に対して使用することはいけないことだと説明 される．また，この力の使用には十分な理由が存 在していなくてはならないとよく言われる。姟妬 や羡みなどの単純な動機によるものは女のウオイ であって，男のウオイでは通用しない，男のウオ イの使用には人々が納得するだけの理由が横たわ っていなくてはならない，例えば，不俱戴天の 敵，出会ら度毎に侮茂の言葉を吐きかけたり，自 分を悩ませる相手，らっかりしていると自分が負 けてしまら競争相手，いくら注意しても妻との密 通をやめない男，牛の支払いなどの義務を果さな い者, 蜂蜜の盗みをやめない者, 氏族会議などの 決定に従わない者などである．また，男のウオイ は頻繁に使用されてはならず一生に 1 度か 2 度で ある．頻度に拈いても抑制的でなくてはならない と言われている．これに対して女のウオイは際限 がないと言われる：ここで男のウオイと女のウオ イの対照的な点を簡単にまとめておくと以下の如 くになる。
男のウオイ

成人した男性が成人した 男性に向って使用するこ 亡を原則とする。女性や 子供に向将られてはいけ ない.

呪医 (mundu mue) によ って作られる呪薬を使用 する.

売買を原則とし遠方より 購入する.他の集団のメ シバーに使用することを 原則とする。

この力の使用には理由や 根拠があると考えられて いる.
女のウオイ

ムオイ (muoi，妖術者) と 呼ばれる特定の女性がその 力を発揮する。相手は子供 でも大人でも，男性でも女 性でも手当り次第である.

呪薬を使用せず，ムオイの 身振り，仕草のみで呪力を 発揮する. 呪力はムオイの 体内の下腹部に存在する.

売買は極めて稀である。こ の力は母から娘に伝達され る.この力は内部集団の者 にも向けられる。

呪力の発揮には何の理由む 根拠もない。たた脄妬や羡 みだけであると考えられて いる.
24) 上田 将 $1974 \mathrm{~b}(39 \sim 40$ ページ) 参照 
この力は抑制して使用さ れなければならない. 頻 繁に使用してはならな W.

この力は奔放である.ムオ イはこのカを余り抑制して いると気が狂らと言われ る.

基本的には社会的に正当 华される。

反社会的で最も邪悪なもの であると考えられている。

男のウオイには難橴のウオイ (uoi wa kyovo) や踊りのウオイ (uoi wa wathi) などと呼ばれる ものも存在する. 難沾のウオイは文字通り人生に おいて次から次に困難な事態が生ずる，病気，飲 酒の悪癖, 金の浪費, 何事をやっても不成功に終 ったり，異性から相手にされない，などで安定し た生活を送ることが出来ない，難渋のウオイでは 死ぬことはないけれども難橴の連続である．踊り のウオイの場合は踊りの競争において相手のグル 一プの踊りを困乱させ, 自分達のグループを勝利 に導びくもので，具体的には歌が乱れる，太鼓を 打ち忘れる, 踊り子の足が捻挫する, 娘たちが発 作（kuia）の状態に陥るなどである．また，恋が たきの若者同士は扔互いが相手をインポテンツに 陷し入れて娘に見放されるように仕向ける。これ らはいずれも死とは結びつかない。しかしキロン ゾのキジーツはウオイの中でも最も恐れられてい る部類に属するもので, それはいつも死と結びつ いている.しかもその死はしばしば即死であるこ とが強調される。

キジーツの所有者は例えば競争相手を倒してく れるよらに依頼を受けると, その依頼者と共にキ ジーツのところに行ってキジーツを木の小枝で打 ちながら呪文を唱える．このことを kuthooa kithitu（キジーツを買うこと）と言う。これはウ オイとしてのキジーツの使用を意味している. キ ジーツの持ち主のンゾカはこの kuthooa kithitu の際にキジーツに向って語りかける，呪文はキジ ーツに語りかける形式をとっている，例えば次の 如くである.

「おい，おい，おい，キジーツよ，一つ頼みご とがあるんだが聞いて欲しい」

「お前は何でもよくわかる，そのことが何であ るかわかってくれ」

「この人は私を悩ませているんだよ，友よ」
「彼を是非つかまえて殺してくれ，放っておか ないでくれ，ムワ．彼を眠らさないようにしてく れ，私の友よ」などである。

キジーツに語りかける言葉の特徵的なことは相 手が死ぬようにと言ら表現がくり返されることで ある.これらの表現からもキジーツがウオイの最 も典型的なものであることを知ることが出来る.

キロンゾがキジーツを Mbeere の呪医 (mundu mue) から購入した時のいきさつは，まさにウオ イとしてのキジーッの特徵を説明している. 当時 キロンゾは解決困難な問題に直面していた. それ はキロンゾの属しているキルティ・サブ・クラン (mbaa Kiluti) の者と,ムリ・サブ・クラン (mbaa Muli)の者が一緒に酒を飲んでいて些細な ことから喧嘩になり，キロンゾの兄弟が弓で射 られて死亡した事件である。キロンン゙はムリ・サ ブ・クランの者に死の弁償 (maambo) を支払う よう要求したが，彼等は自分たちが弓を射たので はないと否定してその支払いに応じょうとしなか った.この死の償いのための牛を「死の弁償の 牛」(ngombe ya maambo) と言う。異なった氏族 (mbai) 間の出来事の場合には死者が男性であれ ば牛 14 頭（雄 4, 雌 10), 死者が女性の場合は 牛 7 頭（雄 1, 雌 6) を支払わなければならな い. 事件を起した当事者は雌牛 1 頭を支払らだけ で，あとは氏族の成員が共同で支払ら義務があ る.この支払いは大変厳密になされるもので，死 亡者が妊婦である場合には解剖されて胎児の性別 が確認されなければならない，最初に夫あるいは 妊娠させた男が死亡した妊婦の腹に灰で線を引 き，ムケンゲーシャ(mukengesya) という草とい っしょにナイフを握って一寸切り傷を入れ，その 後で古老が切開する. 胎児にも上述した方法に従 って牛が母親の分に加算して支払われる. 大人と の支払い上の区別はない，キロンゾがキジーツを 手に入れたのはこの事件を契機にしてである，そ の後, ムリ・サブ・クランの人々は, このキジー ッのために次々に死亡し始めた. 4 人目の死者が 出るに及んでムリ・サブ・クランの者たちは氏族 会議を開いて死の弁償を支払らことを決めた。キ 
ジーツのカが更に他の成員に波及することを恐れ たからである. キジーッの力は弓を射た本人のみ ならずその近親者から他の成員に次々と及んでい $<$.

キロンゾが，その後キジーツをどのように使用 したかについての伝承の中に更にはっきりとウオ イとしての使用を知ることが出来る. 人々の説明 によるとキロンゾは若い時からリーダー (muthiani）としての資質を備えていた. 彼の弁舌は魅力 的であり説得力に富んだものであった. 人々は彼 を好きになり, 彼の言らことに従った. 古老たち も彼に従った. 彼が Mbeere の呪医からキジーツ を購入したのは結婚後であり，これを手に入れて から，次第に呪医と呼ばれるよらになった，氏族 会議にはいつもこのキジーツを持参した. 彼は牛 皮で作った袋（ngusu）にキジーツを入れ，足の 間にはさんでいた，氏族会議に従わない者がいる と，彼はその男に向って「出て行け！」と言っ た. その男が出て行ってのち, キロンゾは氏族会 議の人々に「会議は続けていて下さい，私は一寸 便所に行ってきます」と言ってその場を離れた. キロンゾはその男の足跡を追って行き, その足跡 にキジーツをつけて「死ね」と言った．7つの足 跡のそれぞれにキジーツをつけてこのようにいっ た。その男は家に帰って間もなく背骨 (muongo) が痛んで死んだ. カンバにおいては足跡は大変重 要であり，このようにウオイの対象にもされる. 足跡に仕掛けるウオイとして最も典型的なるのは 足跡のウオイ (uoi wa ndatho) と呼ばれ, 呪薬 のすり込まれた小さな弓で相手の足跡を射る.こ の場合も 7 つの足跡を射る.

キロンゾのキジーツは大変有名になり, キッイ 地区だけでなく，カンバ全体に知られるよらにな り, 遠い所からも人々は彼のキジーツを求めてや って来た. キロンゾは自分の氏族の成員のみでな く他の氏族の成員に対してもキジーツを使用する よらになった. 他の氏族のリーダーたちがキロン ゾの所に氏族会議の決定に従わない者を連れてき た.このよらな場合，キロンゾは先ず，その反対 者に理由を聞き氏族会議の決定に従らように喻し
た. それでもまだ反対するものがいれば，彼が帰 ったのち，夜になってキロンゾは呪文を唱えなが らキジーツを木の小枝で吒いた７回たたいてそ の小枝を折って，反対者が帰った方向に向って投 げすてた.するとその男は家に帰り着かないうち に急に首の骨 (ikoti) が折れて死んだ. 小枝を折 ることはこの場合首の骨を折ることを意味してい る.

キロンゾのキジーツは効果が速く, 上述の例の ように家に帰り着かないらちに死んでしまうか, あるいは 7 歩歩かないらちに倒れるなどと言われ る.このよらにキロンゾのキジーツは典型的な男 のウオイの性質を持っているのである.

以上述べてきた如く，キロンゾのキジーツは多 様な力を内在させている存在である.つまり社会 的正義の主張と結びつく力から個人的な敵対関係 の者に向けられる力まで包括している. 更にキジ 一ツの所有者自身にも種々の影響を与えるもので ある.こらいった多様な力の側面を $1 つ 1 つ$ 明ら かにしていくことが私のキジーツに関する研究の 方向である. そうすることによってキジーツの力 とその性質に関する理解を一層深めることができ ると思う。

\section{附 記}

この報告は 1970 年 12 月より 1973 年 7 月ま でカンバの Kitui District の Kyuso Division において行われた調査に基づくものである. 現地 の人々をはじめ調查に御協力下さいました多くの 人々に心から感謝いたします. 調査のための研究 資金はウ土ナ・グレン人類学援助財団および石橋 財団などの援助によるものです，厚くお礼申し上 げます，調査参加者は筆者と上田冨士子である. なお，キジーツに関する報告は昭和 50 年 5 月京 都大学に打ける第 12 回日本アフリカ学会におい て「ケニア・カンバに拈けるキジーツ信仰につい て」と題して報告した. 


\section{参考文献}

Hobley, C. W. Bantu Beliefs and Magic, with particular reference to the Kikuyu and Kamba tribes of Kenya Colony; together with some reflections on East Africa after the war. Frank Cass. 1967.

Kimilu, D.N. Mukamba wa wo. Nairobi: East African Literature Bureau. 1962.

Lindblom, G. The Akamba in British East Africa: An Ethnological Monograph. Uppsala: Appelbergs Boktryckeri Aktiebolag. 1920.

Middleton, J. and Kershaw, G. The Kikuyu and Kamba of Kenya. London: International African Institute. 1965.

Ndeti, K. The Institution of Kithitu and Question of Human Justice among the Akamba. Journal of Eastern African Research \& Development. Vol. 1, No. 1. Nairobi: East African Literature Bureau. 1971.

Elements of Akamba Life. Nairobi: East African Publishing House. 1972.

Penwill, D. J. Kamba Customary Law. Notes taken in the Machakos District of Kenya Colony. Lon- don: Macmillan. 1951.

Ueda, H. Witchcraft and Sorcery in Kitui of Kamba tribe. Discussion paper, No. 25. Institute of African Studies, Univ. of Nairobi. 1971.

- The Kamba of central Kenya. in Molnos, A. (ed) Cultural source materials for population planning in East Africa, Vol. 2, Innovations and communication. Nairobi: East African Publishing House. 1972.

. The Kamba of central Kenya. in Molnos, A. (ed) Cultural source materials for population planning in East Africa, Vol. 3, Beliefs and practices. Nairobi: East African Publishing House. 1973.

上田 将「ある裁判の記録一妖術事件とムマの儀礼一」 『アフリカの文化と言語』月刊言語別冊 1 , 大修館 $1974 \mathrm{a}$

一一「カンバ族におけるアイムとその䍐依」『教育 と医学』第 22 巻, 第 10 号, 慶応通信 $1974 \mathrm{~b}$

一「ケニヤ・カンバに㧍けるウイッチ」, 『民族学

研究』 39 卷 4 号 1975.

上田 将・上田冨士子「カンバに㧍ける午談関係 (1)」 『民族学研究』 40 巻 3 号 1975.

\title{
Kithitu among the Kamba of Kenya
}

\section{-The Case Study of Kilonzo's kithitu-}

\author{
UEDA Hitoshi
}

In this paper I consider kithitu (pl. ithitu) among the Kamba, a 'Bantu speaking' people in Central Kenya. Kithitu is a kind of magical medicine (muthea) in a broad sense. Its form is a medicine container, such as an animal's horn or a human tibia, in which magical medicine is packed. Medicine is mainly made from plants, but it is very difficult to know the constituents of medicine because secrecy about the ingredients is strictly kept.

There are many kinds and many uses of ithitu among the Kamba, but in this paper I examine Kilonzo's kithitu which is very well-known in the northern part of Kitui District. There are many oral traditions and much gossip about the kithitu in which its potency and the people's fear of it are always expressed.

Here I consider how the Kamba explain the various qualities and power of the kithitu, including:

1. The owner must keep his kithitu in the bush(kitheka)far away from his homestead (musyi). If he puts it in his homestead, the people of his homestead will die because of the strong effective power of the kithitu.

2. After using the kithitu, the owner and the persons concerned must not leave it without wiping off their eyes, hands and the soles of their feet with a mixture of juice from some plants and the soil of an ant hill, or with mwoyo (the undigested contents of a goat's stomach), because they have to cleanse the destructive power of the kithitu before coming back to their homes.

3. The kithitu sometimes comes near to the owner's homestead from the bush and 
cries like a man asking a goat's blood to drink. On such occasions, the owner must kill a goat and take the blood to the kithitu immediately. It is said that if he neglects this, all the members of his homestead will die.

4. The owner of strong kithitu can not have his real sons. It is believed that his real sons die young one after another because he always uses the kithitu.

5. The kithitu is used in oaths as kuya kithitu(to eat kithitu). It has the power to judge the truth. The accuser and the accused go to the bush and each of them swears over the kithitu, saying that if he tells a lie the kithitu may kill him. But people don't swear over the kithitu directly without kusuna kavyu (to lick a hot knife), ordeal as the first step, because the kithitu is so dangerous that a liar is killed with it. Swearing over the kithitu is connected with law, morals, values, legal procedure, clan conferences (mbai), political power and so on.

The kithitu is used as uoi (magical power to knock down an enemy or a rival). When some person encounters serious difficulties brought by his enemy, he visits and asks the owner of the kithitu to kill his enemy. The owner chants a spell against the enemy, striking the kithitu with a twig.

The Kamba categorize $u o i$ into two parts: Uoi wa mundu ume (uoi of man) and $u o i$ wa mundu muka (uoi of woman). The kithitu belongs to the category of uoi of man. It has the characteristics shown below:

(1) A person who wants to use the kithitu must pay money to the owner. It costs about three hundreds shillings (equivalent to about fifteen thousands yen). Kuthooa kithitu (to buy kithitu) means to use kithitu as uoi.

(2) Women and children cannot approach and use the kithitu because administering it is always attended by some danger and secrecy. Only the male adults can use it.

(3) It is forbidden to use the kithitu without socially justified reasons. To use kithitu is basically permitted by the society, but only if people follow the prescribed pattern of usage. The kithitu as $u o i$ is deeply related to the kamba magico-religious beliefs and practices-to revelation, misfortunes, conflicts and so on.

This paper is based on field work conducted in the Kyuso Division, the northern part of Kitui District, Kenya, from December 1970 to July 1973. I am grateful to the WennerGren Foundation, the Ishibashi Foundation and others for their financial support of this field work. 